\title{
33 \\ MODEL PENGEMBANGAN KEPRIBADIAN DI PESANTREN
}

\author{
Muskinul Fuad \\ Program Studi Bimbingan dan Konseling Islam IAIN Purwokerto \\ daufmuskinul@gmail.com
}

\begin{abstract}
This study aims to describe the model of Muslim personality development that is developed based on in-depth observations of what is practiced by the pesantren community in order to develop the personality of their students. This research was conducted with a qualitative approach in the form of ethnography. Subjects were taken from three Islamic boarding schools in Purwokerto City, namely An-Najah Islamic Boarding School, Darussalam Islamic Boarding School, and athThohiriyah Islamic Boarding School. The results showed that the Muslim personality development model practiced by the pesantren community was based on several principles and values that were understood and practiced by the pesantren community, including scientific enthusiasm, independence, responsibility, simplicity, togetherness, leadership, and sincerity. The process of developing students' personality is done through understanding, exemplary, accustomed to, worshiping, and deepening the values of pesantren. The Muslim personality development model that has been practiced in the pesantren community can be said as an answer to the need for a personality development approach that is appropriate to the religious cultural context of Indonesian society. This model is worth discussing as indigenous personality development, which is a pattern of personality development that is rooted in the values, perspectives, or traditions that exist in a community.
\end{abstract}

Keywords: Pesantren, values, personality development, models.

Abstrak: Penelitian ini bertujuan untuk menggambarkan model pengembangan kepribadian muslim yang dikembangkan berdasarkan pengamatan yang mendalam terhadap apa yang dipraktekkan oleh komunitas pesantren dalam rangka mengembangkan kepribadian para santrinya. Penelitian ini dilakukan dengan pendekatan kualitatif dalam bentuk etnografi. Subyek diambil dari tiga pondok pesantren yang ada di Kota Purwokerto, yaitu Pondok Pesantren An-Najah, Pondok Pesantren Darussalam, dan Pondok Pesantren ath-Thohiriyah. Hasil penelitian menunjukkan bahwa model pengembangan kepribadian muslim yang dipraktekkan oleh komunitas pesantren dilandasi oleh beberapa prinsip dan nilai-nilai yang dipahami dan dipraktekkan oleh komunitas pesantren, meliputi semangat keilmuan, kemandirian, tanggungjawab, kesederhanaan, kebersamaan, kepemimpinan, dan keikhlasan. Proses pengembangan kepribadian santri dilakukan melalui pemahaman, keteladanan, pembiasaan, ibadah, dan pendalaman nilai-nilai pesantren. Model pengembangan kepribadian muslim yang telah dipraktekkan dalam komunitas pesantren ini dapat dikatakan sebagai sebuah jawaban terhadap kebutuhan akan pendekatan pengembangan kepribadian yang sesuai dengan konteks budaya keagamaan masyarakat Indonesia. Model ini layak untuk diwacanakan sebagai indigenous personality development, yaitu sebuah pola pengembangan kepribadian yang berakar pada nilainilai, cara pandang, atau tradisi yang ada dalam sebuah komunitas.

Kata Kunci: Pesantren, nilai, pengembangan kepribadian, model. 


\section{A. Pendahuluan}

Di tengah berbagai persoalan bangsa dan dunia saat ini, pesantren semakin ditantang untuk dapat mengejawantahkan misi kenabian dalam praktek pendidikannya, yaitu menyempurnakan akhlak mulia. Pesantren diharapkan dapat menjadi pionir dalam gerakan moral membangun karakter bangsa yang diawali dari upaya pengembangan pribadi para santrinya. Untuk itu, pesantren harus merujuk kembali kepada khazanah dan tradisi Islam yang kaya dengan prinsipprinsip dan pola pengembangan akhlak mulia. Para Kyai dan santri di pesantren kaya akan pemikiran dan praktek pendidikan karakter yang telah dikembangkan oleh tokoh-tokoh seperti Al-Ghazali, Ibnu Maskawih, dan Az-Zarnuji.

Tuntutan terhadap pesantren tersebut sesungguhnya memiliki alasan yang sangat kuat, mengingat terdapatnya segala potensi yang ada di lembaga pendidikan khas Indonesia ini. Pesantren merupakan sebuah lembaga pendidikan yang memiliki karakteristik dan dinamikanya sendiri, apabila dibandingkan dengan lembaga pendidikan formal seperti sekolah. ${ }^{808}$ Salah satu yang tampak adalah apa yang ada pada kehidupan santrinya. Para santri hidup dan tinggal terpisah dengan orangtua, bertempat di asrama (pondokan), berinteraksi dengan teman-teman, para ustadz, dan pengasuh (kyai), selama 24 jam, dalam sebuah komunitas bernama pesantren. Aktivitas keseharian santri dapat dikatakan lebih bervariasi, kompleks, dan dinamis, dibandingkan dengan seorang siswa di sekolah. Aktivitas itu secara umum meliputi kegiatan belajar agama (mengaji) seperti sorogan, bandungan, halaqah, atau musyafahah, dan kegiatan pribadi seperti mandi, mencuci, tidur, makan, dan olahraga, serta berbagai aktivitas ibadah seperti zikir, shalat berjamaah, puasa sunnah, dan tadarrus. Di dalam pesantren yang membuka lembaga pendidikan formal (sekolah), aktivitas santrinya akan bertambah dengan kegiatan belajar di sekolah secara klasikal. ${ }^{809}$

Dilihat dari output-nya, pesantren telah berhasil pula dalam melahirkan sosok-sosok pribadi yang diakui perannya dalam skala nasional, misalnya Gus Dur, Hasyim Muzadi, Said Aqil Siradj, Din Syamsuddin, Musthofa Bisri, Nurkholis Madjid, Hidayat Nur Wahid, Emha Ainun Najib, Sholahuddin Wahid, dan lainnya. Para alumi pesantren ini tidak dapat dipungkiri merupakan tokoh yang telah mewarnai perjalanan bangsa ini dengan kontribusinya di bidang masingmasing, baik dalam pemikiran kebangsaan, keislaman, dan sastra, maupun dalam hal kepemimpinan organisasi sosial kemasyarakatan, lembaga pendidikan, dan politik nasional. Ketokohan mereka tentu saja tidak dapat dipisahkan dari model pengembangan kepribadian yang ada di dunia pesantren.

Dilihat dari teori kepribadian, dinamika kehidupan pesantren tersebut akan membawa konsekuensi yang lebih kompleks bagi kehidupan para santrinya. ${ }^{810}$ Pada satu sisi, hal ini akan potensial menimbulkan berbagai permasalahan psikologis bagi santri. Akan tetapi, pada sisi yang lain, dinamika tersebut akan menjadi sarana yang efektif bagi pengembangan kepribadian para santri. Santri adalah individu yang ditempa dengan berbagai pola kehidupan pesantren yang menekankan pada kemandirian, moralitas, kesederhanaan, dan kesabaran.

Sebagai alumni pesantren, penulis merasakan kerinduan akan hadirnya kembali pola atau model pengembangan kepribadian muslim yang tampaknya mulai diabaikan oleh dunia pesantren sendiri. Untuk itu, melalui penelitian di beberapa pesantren yang ada di Kota Purwokerto, penulis tertarik untuk mengungkap kembali model pengembangan kepribadian muslim yang ada di dunia pesantren. Hanya saja, sebelum sampai pada rumusan model

${ }^{808}$ Hasil bacaan penulis terhadap disertasi Mastuhu (1994). Dinamika Sistem Pendidikan Pesantren, Jakarta: INIS. Lihat pula Hasyim, Yusuf (2008). Model Penelitian Kultur Pendidikan Islam Dr. Mastuhu Tentang Dinamika Sistem Pendidikan Pesantren. [Online]. Tersedia:

https://gurubangsaku.wordpress.com/2008/10/28/dinamika-sistem-pendidikan-pesantren

${ }^{809}$ Muskinul Fuad dan Alif Budiono (2012). "Pola Kelekatan di Kalangan Santri Usia Remaja Awal: Studi Kasus di Pondok Pesantren Anwarussholihin Pamujan Teluk, Banyumas" dalam Jurnal Personifikasi Vol 3, Nomor 2, November 2012.

810 Sebagai contoh, Lihat Khoiruddin Bashori (2003). Problem Psikologis Kaum Santri: Resiko Insekuritas Kelekatan. Yogyakarta: FKBA. 
pengembangan kepribadian yang ada di pesantren, penulis merasa perlu untuk menggali nilainilai yang mendasari praktek pengembangan kepribadian yang dimiliki oleh pesantren dan bagaimana prosesnya di lapangan. Dengan penelitian ini, penulis berharap dapat merekonstruksi kembali pola atau model pengembangan kepribadian yang ada dalam tradisi pesantren.

Penelitian ini dilakukan dengan pendekatan kualitatif dalam bentuk etnografi, yaitu sebuah pendekatan untuk mengembangkan pemahaman terhadap aktivitas atau perilaku sehari-hari dari sekelompok orang dalam seting tertentu. Paradigma yang digunakan adalah postpositivistik, yaitu cara pandang penelitian yang bersifat interpretif, konstruktif, dan berlangsung dalam seting alamiah (natural setting). Secara garis besar data-data dalam penelitian ini dikumpulkan melalui tiga teknik yaitu observasi partisipatif, wawancara, dan dokumentasi. Analisis yang dilakukan peneliti bersifat induktif, deskriptif, dan kualitatif. Prosesnya dilakukan baik sebelum di lapangan, selama di lapangan, ataupun setelah di lapangan.

\section{B. Nilai-nilai Pesantren sebagai Landasan Pengembangan Kepribadian Santri}

Selanjutnya, berdasarkan studi lapangan di tiga pesantren yang menjadi lokus penelitian ini, penulis menemukan nilai-nilai yang menjadi landasan pengembangan kepribadian santri, yang selanjutnya bermuara pada ciri atau karakteristik kepribadian santri. Nilai-nilai tersebut adalah sebagai berikut:

\section{Nilai Keilmuan}

Sebagaimana dinyatakan oleh Suparjo, etos intelektual merupakan identitas kultural dari komunitas pesantren. Hal ini karena seluruh perikehidupan santri di pesantren merupakan sebuah proses pendidikan atau pencarian ilmu. Hampir seluruh waktu santri digunakan untuk untuk belajar; yaitu mengaji dan sekolah, dan ibadah mahdhah, bahkan kegiatan mengaji dan sekolah ini diniatkan pula sebagai ibadah. Selebihnya, santri memiliki sedikit waktu luang untuk kegiatan pribadi dan istirahat. Nilai atau etos keilmuan santri ini sungguhnya dipengaruhi oleh sikap, pandangan, dan kehidupan kyai dan para ustadz sehari-hari. Perikehidupan kyai dan ustadz biasanya meliputi aktivitas mengaji, beribadah, dan mencari nafkah untuk memenuhi kebutuhan keluarga. Dilihat dari perannya, Kyai adalah murabbi (pendidik dan pengajar) bagi para santrinya, sedangkan para santri adalah murid yang menjadi ibnu sabil atau pengelana ilmu..$^{811}$

Di pesantren an Najah, ath-Thohiriyah, dan Darussalam, etos keilmuan kyai dan santri dapat ditangkap dari padatnya aktivitas pengajian santri, dari sejak bangun tidur sampai menjelang tidur. Sejak bangun tidur, setelah Sholat Subuh, santri sudah harus mengikuti pengajian bandungan (pengajian kitab secara kelompok besar) atau pengajian Al-qur'an secara musyafahah. Selanjutnya, setelah mandi dan sarapan pagi, mereka belajar di bangku pendidikan formal, sesuai sekolah dan kampus masing-masing, sampai siang dan sore hari. Di sore hari, sekembalinya ke pesantren, para santri kembali disibukkan dengan aktivitas mengaji di pesantren, baik secara klasikal maupun non klasikal. Dengan demikian, dilihat dari dayly activities yang ada di pesantren, maka dapat dikatakan bahwa $90 \%$ nya adalah aktivitas "ngelmu".

Nilai-nilai keilmuan yang dimiliki santri tampaknya merupakan refleksi dari nilai-nilai keilmuan para kiyai dan ustadznya. Misalnya, Bapak pengasuh pondok pesantren Darussalam adalah seorang alumni pesantren, mubaligh terkenal, Dosen di IAIN Purwokerto, dan Doktor lulusan Program Pascasarjana UIN Sunan Kalijaga Yogyakarta. Demikian pula halnya dengan Ibu pengasuh yang seorang hafidzah, bergelar S2, dan seorang guru di MAN di Kota Purwoketo. Demikian pula dengan anak-anak dan menantu mereka. Salah seorang putri pengasuh adalah seorang dokter lulusan sebuah PTN di Purwokerto, sedangkan yang lain ada yang telah lulus S 2 serta ada pula yang sedang menempuh pendidikan S 3. Setiap hari para santri di pesantren ini tentu saja dapat menyaksikan bagaimana para ustadz yang umumnya adalah para guru dan lulusan S2

${ }^{811}$ Lihat Suparjo (2014). Komunikasi Interpersonal Kyai-Santri: Keberlangsungan Tradisi Pesantren di Era Modern. Purwokerto: STAIN Press, hal. 31 
selalu bergelut dengan aktivitas mengajar, kuliah, belajar, membaca buku, dan berinteraksi dengan para santri dalam kegiatan belajar-mengajar. Hal ini tentu saja akan mempengaruhi dan menginspirasi para santri untuk senantiasa menjadi orang yang senang belajar dan mau melanjutkan studi setinggi-tingginya, misalnya ke jenjang S 2 atau S 3.

Sebagaimana halnya dengan Pesantren Darussalam, Pesantren an-Najah adalah sebuah pesantren yang sangat menjunjung tinggi nilai keilmuan, jika mengingat bahwa para santrinya adalah para mahasiswa dari berbagai perguruan tinggi di Purwokerto, terutama IAIN Purwokerto. Dari aktivitas jadual kegiatan di pesantren ini, yang tidak berbeda jauh dengan Pesantren Darussalam, tercermin bahwa aktivitas harian santri tidak jauh dari kuliah dan "ngaji". Demikian pula dengan pengasuh dan ustadz-ustadznya. Sang pengasuh, yang biasa dipanggil Abah Roqib oleh para santrinya, adalah seorang Dosen di IAIN Puwokerto. Peran sebagai dosen dan kiyai ini tentu saja tidak akan jauh dari aktivitas membaca kitab kuning, buku, seminar, diskusi, menulis makalah, dan sebagainya. ${ }^{812}$ Demikian pula halnya dengan para ustadz di pesantren ini yang sebagian besar adalah alumni pesantren dan juga dosen di berbagai perguruan tinggi di Purwokerto. Hal ini tentu saja akan memberikan inspirasi dan motivasi kepada para santri tentang pentingnya ilmu dan upaya mencari ilmu, baik dari bangku formal (kuliah) maupun dari pesantren. Beberapa santri senior atau pengurus pesantren ini terbukti kemudian melanjutkan pendidikannya ke Pascasarjana (Strata 2).

Berbeda halnya dengan dua pesantren sebelumnya, pengasuh pesantren Ath-thohiriyah bukanlah sosok yang dilahirkan dari bangku perguruan tinggi (dengan gelar akademik). Nilai keilmuan yang dimiliki oleh sang pengasuh, Abuya Toha, tercermin dari latar belakang beliau yang merupakan seorang hafidz Qur'an, alumni dari berbagai pesantren di Jawa, dan pernah tinggal di Mekkah untuk memperdalam ilmu al-Qur'an. Meskipun bukan orang "sekolahan", Abuya selalu memotivasi para santrinya agar dapat menuntut ilmu setingi-tingginya, baik secara formal (kuliah) maupun non-formal, yaitu dengan menuntut ilmu di pesantren lainnya, sebagaimana diakui oleh salah seorang santrinya kepada penulis. Terlebih lagi, Abuya juga memiliki 10 orang putra-putri yang juga dikirim pesantren atau belajar ke Mesir. ${ }^{813}$

Semangat keilmuan yang dimiliki oleh para pengasuh dan ustadz pesantrean pada dasarnya merupakan nilai yang akan memfasilitasi dan mengantarkan para santri agar dapat menjadi sosok (pribadi) yang cinta ilmu, mengutamakan ilmu, dan terbuka terhadap ilmu. Hal ini dibarengi dengan adanya pentingnya nilai kesabaran, ketabahan, keikhlasan, dan keistiqamahan dalam menuntut ilmu. Hal inilah yang selalu ditanamkan oleh para Kyai da para ustadz di pesantren.

Semangat keilmuan ini tidak saja ditekankan dalam hal menuntut ilmu agama (kepesantrenan), tetapi juga ilmu-imu umum, sesuai dengan disiplin keilmuan (jurusan) yang ditekuni oleh para santri di sekolah dan perguruan tinggi. Para pengasuh dan para ustadz dari ketiga pesantren ini ampaknya tidak pernah melakukan diskriminasi (dikotomi) terhadap ilmu agama dan ilmu umum. Meskipun misalnya Abuya Toha sangat menekankan pentingnya kuliah, tetapi beliau tetap memberi batasan agar tidak menomorsatukan aktivitas kuliah dan mengalahkan aktivitas pesantren. Artinya, para kiyai di ketiga pesantren ini mampu mengambil sikap yang sama terhadap ilmu agama maupun ilmu umum secara komplementer, bukan menegasikan salah satu di antara keduanya. Jadi, antara "sekolah" dan "ngaji" tidak perlu dipertentangkan, karena keduanya dianggap sama-sama penting. Hal ini tampaknya memperkuat tesis Lukens-Bull tentang keberhasilan pesantren dalam melakukan penyesuaian diri terhadap nilai-nilai kemodernan, khususnya terhadap kebutuhan terhadap ilmu pengetahua umum (sains). 814

Nilai keilmuan di pesantren tampak pula dari bervariasinya kitab-kitab kuning yang dikaji oleh civitas akademikanya, mulai dari kitab fiqih seperti fathul qarib, kitab akidah, kitab tafsir, kitab hadits, kitab tasawuf, dan sebagainya. Kajian terhadap beragam kitab klasik yang ditulis oleh para

${ }^{812}$ Seorang santri PP. an Najah mengungkapkan bahwa ia biasa menyaksikan kyainya yang sangat lama dalam membaca buku. Hal ini mendorong ia untuk dapat mengikuti jejaknya.

${ }^{813}$ Wawancara dengan Agung, salah seorang santri PP. Ath-thohiriyah, pada tanggal 16 September 2015

${ }^{814}$ Lukens-Bull (1998). Teaching Morality: Javanese Islamic Education in Globalizing Era. Disertasi. Arizona University Southeast Asia. Hal. 1 
ulama terkemuka ini menunjukkan bahwa santri di pesantren dibiasakan untuk menghargai karya ilmiah-keagamaan dan selalu menjaga ketersambungan dengan orang-orang yang berilmu yang autoritatif di bidang keilmuannya. Terlebih lagi, di pesantren biasanya selalu dikaji sebuah kitab yang membahas aspek-aspek terkait dengan keilmuan yaitu kitab ta'limul muta'allim. Kitab ini membahas keutamaan dan kedudukan ilmu, etika mencari ilmu, dan klasifikasi ilmu, Kitab ini dikaji baik dalam bentuk sorogan maupun bandungan. Di pesantren an Najah, orientasi keilmuan (akademik) tidak saja dapat dilihat dari aktivitas para kyai, ustadz, dan santrinya dalam kuliah, "ngaji", membaca dan mengkaji kitab kuning atau buku, tetapi terlihat pula dalam kegiatan seperti Studi Islam Intensif Liburan (SIIL), serta latihan dan lomba kepenulisan. Sebagaimana telah diungkap di atas, pengasuh, ustadz, dan sebagian santri di pesantren ini telah menulis beberapa karya buku, baik ilmiah maupun non ilmiah (sastra).

\section{Nilai Kemandirian dan Tanggungjawab}

Nilai yang menjadi ciri khas pesantren berikutnya adalah orientasi pesantren dalam membentuk santrinya agar dapat menjadi pribadi yang mandiri dan bertanggungjawab. Hal ini tercermin dalam mekanisme kehidupan pesantren yang membiasakan santri untuk melakukan aktivitas pribadi seperti mencuci baju, mengatur keuangan untuk kebutuhan sehari-hari, dan mengatur waktu. Meskipun saat ini telah banyak bermunculan jasa cuci-seterika (laundry), umumnya pesantren masih menekankan para santri untuk dapat mencuci bajunya sendiri. Hal ini tentu saja membuat santri untuk teriasa hidup mandiri.

Nilai tanggungjawab ditanamkan oleh pengasuh melalui pemberian wewenang kepada para santri untuk membuat kepengurusan santri yang bertugas mengatur atau mengelola berbagai aspek terkait dengan keberlangsungan kehidupan santri di pesantren, misalnya terkait dengan kegiatan belajar mengajar, keamanan, kebersihan, pengembangan bakat dan minat santri, olahraga, konsumsi, dan sebagainya. Hal ini ditambah pula dengan adanya aktivitas (acara) insidental di dalam pesantren, baik yang diprogramkan oleh pesantren sendiri maupun berbagai kegiatan oleh pihak luar yang mengambil tempat di pesantren tersebut.

Untuk kegiatan yang bersifat insidental dan diprogramkan oleh pesantren sendiri misalnya adalah kegiata akhirussanah, khataman, pengajian umum, seminar, dan sebagainya. Untuk mensukseskan acara ini, pengasuh biasanya mendelegasikan santri untuk membentuk kepanitiaan tertentu, dengan melibatkan seluruh santri untuk berpartisipasi dalam acara ini. Panitia inilah yang akan bertugas dalam menyiapkan jadwal acara, membuat proposal dan anggaran, menghubungi pembicara, mencari dana, penyiapan tempat mengatur perpakiran dan keamanan, kebersihan, pengadaan sound system, dan sebagainya. ${ }^{815}$ Pola ini akan memberi kesempatan kepada semua santri untuk dapat berlatih dalam menunaikan tanggung jawab atau tugas.

Sikap kemandirian dan penuh tanggung jawab merupakan modal pribadi yang sangat bermanfaat bagi para santri ketika mereka nantinya telah memasuki usia dewasa, yaitu saat hidup berkeluarga dan bermasyarakat. Sebagai anggota keluarga, mereka akan menjadi seorang suami atau isteri yang akan berpisah dari orangtuanya sekarang, kemudian hidup mandiri, mencari nafkah, dan membesarkan anak-anak mereka. Secara eksternal, mereka juga akan hidup sebagai pribadi yang tidak akan lepas dari tugas menjalankan tanggung jawab (tugas) di tempat kerja dan di tengah-tengah masyarakat pada umumnya. Dengan bekal yang telah didapatkan di pesantren, para alumni di pesantren akan hidup sebagai pribadi yang dewasa, matang, serta tidak menyusahkan orang lain

\section{Nilai Kesederhanaan}

Nilai ini dapat dilihat dari adanya pola hidup sederhana yang dibiasakan di pesantren. Misalnya, dilihat dari asrama (tempat tinggal santri), para santri umumnya harus tinggal cukup berdesakan dalam sebuah bilik kamar. Saat malam tiba, mereka harus tidur dengan alas sederhana

\footnotetext{
${ }^{815} \mathrm{Hal}$ ini diakui oleh salah seorang santri PP. Ath-thohiriyah, yang menyatakan bahwa ia pernah memiliki pengalaman berharga saat ditunjuk menjadi ketua panitia dalam sebuah acara tahunan di pesantrennya.
} 
dari tikar atau kasur tipis tanpa dipan dan fasilitas lain yang biasanya terdapat di hotel atau koskosan. Apabila biasanya satu kamar kos-kosan dihuni oleh satu atau dua orang mahasiswa (siswa), maka satu kamar di pesantren dapat dihuni sampai 10 orang santri. Bahkan, bagi pesantren yang model asramanya adalah ruangan sebesar ruangan kelas, maka penghuninya menjadi lebih banyak. ${ }^{816}$

Biaya makan di pesantren umumnya juga tidak terlalu mahal, karena pihak pesantren memahami betul latar belakang sebagian besar para santrinya, yang memang bukan dari keluarga berada. Meskipun tidak seperti pesantren jaman dulu, yang sangat kental kebersahajaannya, ketiga pesantren, yaitu an Najah, Ath-thohiriyah, dan Darussalam, tetap menampakkan nilai-nilai kesederhanaannya. Misalnya, di ketiga pesantren ini terdapat batasan dalam menonton TV, mengakses internet, penggunanaan hand phone, dan sebagainya. Aturan seperti ini pada dasarnya merupakan bentuk pengkondisian agar para santri tidak biasa manja dan bernyaman-nyaman ria dengan segala fasilitas atau teknologi.

Adanya nilai-nilai kesederhanaan yang dimiliki pesantren mengindikasikan bahwa para santri nantinya diharapkan akan menjadi individu yang hidup sederhana atau tidak bermewahmewah. Pilihan ini tidak berarti kemudian melarang santri untuk menjadi orang kaya, melainkan sebuah nilai yang menekankan bahwa dalam hidupnya seorang muslim sesungguhnya adalah pribadi yang tidak terlena dengan kekayaan dan harta yang dimilikinya. Dalam khazanah tasawuf dikenal sebuah sikap hidup yang dianggap negatif, dan harus dijauhi oleh seorang musim, yaitu hubbud dunya (cinta harta).

\section{Nilai Sosial dan Kebersamaan}

Nilai ini dapat dipahami dari bagaimana mekanisme hidup yang ada di di sebuah miniatur kehidupan yang bernama pesantren. Mekanisme kehidupan ini diwarnai dengan nilai-nilai kebersamaan, persaudaraan, dan kegotongroyongan. Nilai ini dapat ditangkap dari bagaimana ketika para santri menunaikan shalat berjamaah, dzikir bersama, ngantri mandi, tidur bersama, makan bersama, ronda bersama, belajar bersama, kerja bakti bersama, olah raga bersama, dan sebagainya. Peri-kehidupan sosial seperti ini sejatinya akan membentuk muslim yang tumbuh menjadi pribadi yang peduli, mau berbagi, dan tidak egois. Berbeda dengan budaya barat yang cenderung individualistis, pesantren cenderung menekankan budaya komunal atau kebersamaan.

\section{Nilai Demokrasi dan Kepemimpinan}

Nilai ini dapat ditangkap dari mekanisme kehidupan pesantren yang diwarnai oleh struktur pesantren yang mirip dengan sebuah pemerintahan dalam sebuah wilayah. Di pesantren terdapat struktur yang menggambarkan bahwa pengasuh adalah top leader yang menjadi pemimpin tertinggi yang bertugas mengarahkan pesantrennya ke arah visi yang hendak dicapainya. Selanjutnya, para ustadz yang lebih konsen dalam menjalankan tugas mendidik dan mengajar para santrinya, kemudian di bawahnya terdapat pengurus, biasanya terdiri dari Lurah (dijabat oleh santri senior) dan seksi atau departemen yang dijabat oleh santri-santri yang lebih yunior. Mereka bertugas mengatur segala aktivitas kehidupan dan kebutuhan santri di pesantren. Para pengurus ini biasanya sering mengadakan rapat atau musyawarah bersama, misalnya dalam menentukan jabatan (memilih orang dalam sebuah kepanitiaan), merencanakan, melaksanakan, dan mengevaluasi program (kegiatan). Kepengurusan ini bekerja dalam sebuah periode kepemimpinan dan bertanggungjawab langsung kepada pengasuh.

Menurut pengakuan seorang santri di Ath-thohoriyah, yang pernah mendapatkan amanah sebagai ketua panitia dalam sebuah kegiatan pesantren, ia merasa mendapatkan sebuah pengalaman berharga saat harus mengatur teman-temannya, mendelegasikan tugas, dan saat

${ }^{816}$ Dalam sebuah kesempatan wawancara dan observasi di PP. an Najah, penulis menyaksikan langsung adanya orangtua santri yang mohon kepada pengasuh agar anaknya dapat tinggal di luar pesantren, agar bisa lebih nyaman dan tingggal sendirian dalam satu kamar, karena anaknya tidak biasa tidur di lantai dan tinggal beramai-ramai di kamar. Terdapat pula orangtua yang mau memasukkan anaknya ke pesantren ini, tetapi dengan permintaan kamar yang khusus. 
menghadapi berbagai orang dengan berbagai latar belakang. Di lain kesempatan, seorang santri lain harus memimpin diskusi (musyawarah) dalam sebuah kegiatan belajar bersama yang membahas berbagai permasalahn fikih atau kitab tertentu. Dalam forum ini santri tersebut banyak belajar soal membagi waktu, memberi kesempatan kepada audiens, menyimpulkan, menghargai perbedaan (toleransi), dan sebagainya. Dalam kesempatan lain, santri bisa saja akan mendapatkan kesempatan untuk menjadi imam shalat, imam tahlil, dan sebagainya. Pengalaman-pengalaman seperti ini tentu saja akan membentuk jiwa kepemimpinan pada diri santri. Hal ini sangat penting bagi pengembangan pribadi santri yang akan sangat bermanfaat ketika nantinya ia setelah keluar dari pesantren harus dapat memimpin keluarga, organsasi, dan masyarakat.

\section{Nilai Spiritualitas dan Moralitas}

Dua nilai ini sesungguhya merupakan aspek yang terkait dengan nilai ketuhanan (rabbaniyyah) yang melandasi setiap gerak pesantren. Nilai ketuhanan inilah yang menjadi orientasi, titik tolak, sekaligus visi pengembangan pribadi santri. Sebagai contoh, di pesantren terdapat sebuah keyakinan bahwa mencari ilmu (ngaji) adalah sebuah bentuk ibadah dan ilmu adalah berasal dari Allah, sehingga santri harus sering-sering memohon kepada Allah agar dapat diberi kemudahan belajar, diberi kepahaman, dan diberi imu yang bermanfaat, dalam rangka menggapai ridla-Nya. Tanpa ruh ini tentu saja psantren hanya tinggal bangunan fisik yang tak akan banyak berarti. Nilai ketuhanan inilah yang kemudian melahirkan buah dalam bentuk perilaku santri yang menjunjung moralitas. Moralitas di sini sangat terkait dengan bagaimana santri menjaga perilaku dirinya agar selalu mengarah kepada hal-hal yang baik; misalnya menjaga shalat lima waktu, mudah membantu orang lain, dan peduli kepada masyarakat, serta menjauhkan diri dari hal-hal yang tidak diperkenankan oleh syara', misalnya dalam hal pergaulan dengan lawan jenis, menutup aurat, dan sebagainya. Tidak berlebihan jika kemudian dikatakan bahwa praktek pendidikan yang ada di pesantren adalah merupakan sebuah bentuk bimbingan ketuhanan (divine guidance).

Istilah divine guidance dapat diartikan sebagai pendidikan dan pengajaran yang berlandaskan nilai-nilai spiritual-keagamaan. Prinsip ini dapat dijadikan ruh pendidikan di pesantren. Artinya, segala aktivitas pedidikan dan pengembangan pribadi santri di pesantren sesungguhnya harus berangkat pada keyakinan bahwa dalam mendidik santri, peran seorang pengasuh tidak dapat terlepas dari pertolongan Allah. Nilai semacam ini sesungguhnya telah dimiliki oleh para kyai di pesantren. Segala aktivitas kehidupan pesantren biasanya akan dilandasi dengan do'a, wirid, shalat malam, puasa sunnah, dan sebagainya. Dengan cara semacam ini, pengasuh atau kyai di pesantren biasanya telah memiliki kekuatan ruhiyah untuk dapat membimbing para santrinya, termasuk ketika harus menyelesaikan berbagai permasalahan yang dialami oleh para santrinya. Amalan-amalan tersebut tidak saja dilakukan oleh kyai sebagai pengasuh atau pendidik, tetapi diamalkan pula oleh para santri secara keseluruhan. Kekuatan spiritual semacam inilah yang selama ini tidak diperhatikan oleh para ahli pendidikan dan pengembangan diri yang sekuler. Mereka tidak menyadari bahwa pendidikan dan pengembangan pribadi yang sejati seharusnya merupakan aktifitas memohon pertolongan Allah untuk dapat membimbing para individu dalam berbagai aspeknya.

\section{Proses Pengembangan Kepribadian Muslim di Pesantren}

\section{Proses Pengembangan Kepribadian Santri Melalui Modelling (peneladanan).}

Peneladanan yang dimaksud di sini adalah proses mencontoh pemikiran, sikap, sifat-sifat, dan perilaku orang-orang yang dikagumi untuk kemudian mengambil-alihnya menjadi sikap, sifat, dan perilaku pribadi. Hal ini terjadi dalam dua ragam peneladanan, yaitu peniruan (imitation) dan identifikasi diri (self-identification). Peniruan adalah upaya untuk menampilkan diri dan berlaku seperti penampilan dan perilaku orang yang menjadi idola (dikagumi), sementara identifikasi diri adalah pengambil-alihan nilai-nilai (values) dari tokoh-tokoh yang dikagumi untuk selanjutnya dijadikan nilai-nilai pribadi (personal values) yang berfungsi sebagai pedoman dan arah 
pengembangan diri.817 Dalam pesantren, saat memberikan pengajian, kyai atau ustadz biasanya memanfaatkan kisah-kisah inspiratif dan bernuansa keteladanan untuk menguatkan nasihat yang mereka sampaikan dalam forum. Kisah-kisah ini bersumber dari kisah Nabi, sahabat, ulama, atau tokoh-tokoh dalam bidang tertentu, yang dibaca dari buku sirah, internet, majalah, surat kabar, dan pengalaman sehari-hari. Dari bacaan terhadap kisah-kisah ini, kemudian dilakukan sebuah perenungan dan ajakan untuk bersama-sama mengambil hikmah yang ada di dalamnya, serta menerapkannya dalam kehidupan sehari-hari.

Proses identifikasi atau peneladanan yang ada dalam pesantren dapat dilihat pula dalam konteks interaksi atau relasi antara kyai (dan ustadz) dengan para santrinya. Beberapa kualifikasi pribadi yang biasanya dimiliki oleh seorang kyai, yang meliputi dimensi ruhiyah (spiritual), fikriyah (intelektual), dan sulukiyah (perilaku) mengandung isyarat bahwa dalam pesantren terjadi proses bimbingan dan pembinaan melalui bahasa perbuatan. Artinya, para santri secara tidak langsung akan mengubah sifat dan perilakunya atau mengembangkan dirinya ke arah yang lebih baik dengan cara melakukan identifikasi diri terhadap kyai sebagai pembimbingnya. Demikian halnya dengan hubungan santri dengan para ustadz yang mengajar di pesantren. Sebagaimana dapat dibaca dalam dalam profil ketiga pesantren, para ustadz di pesantren an Najah, Aththohiriyah, dan Darussalam, adalah para pribadi yang memiliki keahlian di bidang masing-masing, misalnya sebagai guru dan dosen. Dalam interaksi antara santri-kyai dan santri-ustadz terdapat sebuah proses identifikasi yang sangat efektif bagi pembentukan pribadi santri. Tidak menutup kemungkinan pula bahwa, dalam aspek-aspek tertentu, antara santri yang satu, biasanya yang lebih senior, dengan santri yang lain akan terjadi proses saling mencontoh (meneladani).

\section{Proses Pengembangan Kepribadian Santri Melalui Pembiasaan Diri}

Pembiasaan diri adalah melakukan suatu perbuatan yang positif atau keterampilan secara terus-menerus secara konsisten dalam jangka waktu yang cukup lama, sehingga perbuatan atau keterampilan tersebut benar-benar dikuasai dan akhirnya menjadi sebuah kebiasaan yang sulit ditinggalkan. Proses ini biasa disebut dengan conditioning. Proses ini akan menjelma menjadi kebiasaan (habit), kebisaan (ability), dan akhirnya menjadi sifat-sifat pribadi (personal traits) yang terwujud dalam perilaku sehari-hari.818 Dalam pesantren, kyai, ustadz, dan para santri biasanya mengkondisikan secara bersama-sama untuk memahami arti penting nilai-nilai akhlak mahmudah, menanamkan, saling mengingatkan, dan membiasakannya dalam kehidupan sehari-hari, baik saat bersama maupun sendiri. Beberapa tindakan positif yang dipraktekkan atau dibiasakan di dalam pesantren adalah meliputi shalat berjama' ah, membaca Al-Qur'an, membaca buku, wiridan, piket kebersihan, dan sebagainya. Pembiasaan tindakan positif yang dilakukan oleh komunitas pesantren ini pada dasarnya merupakan implementasi dari tujuan pengembangan kepribadian muslim yang dalam bahasa Hasan al Banna dirumuskan sebagai membentuk sosok pribadi muslim yang berakidah lurus, beribadah dengan benar, berakhlak tangguh, mampu bekerja atau mandiri, berwawasan luas, berbadan sehat dan kuat, memiliki etos kerja yang tinggi, tertata urusannya, efektif dengan waktunya, dan bermanfaat bagi orang lain. Aspek pembiasaan secara bersama-sama yang ditumbuhkan dalam pesantren sesungguhnya juga merupakan upaya komunitas pesantren untuk senantiasa menjaga komitmen seorang muslim terhadap Islam itu sendiri. Komitmen ini mencakup bagaimana mereka senantiasa meneguhkan akidah (keyakinan) mereka terhadap Islam, berpikir, beramal, dan berakhlak dengan nilai-nilai islam. Komitmen muslim sejati tidak akan terlalu efektif apabila dilakukan secara sendiri-sendiri, melainkan diperlukan sebuah upaya bersama-sama atau jama'ah. Pesantren adalah komunitas yang akan memfasilitasi para anggotanya dalam membangun komitmen mereka sebagai muslim.

\footnotetext{
817 Bastaman (2007). Logoterapi: Psikologi untuk Menenmukan Makna Hidup dan Meraih Hidup Bermakna. Jakarta: Rajawali Pers, hal. 151.

818 Bastaman, H.D (1997). Integrasi Psikologi dan Islam. Jakarta: Pustaka Pelajar. Hal.126.
} 


\section{Proses Pengembangan Kepribadian Santri Melalui Pemahaman}

Yang dimaksud dengan pemahaman diri adalah proses mengenali secara obyektif berbagai kekuatan dan kelemahan diri, baik yang potensial maupun yang telah teraktualisasi, dan kemudian mengembangkan atau meningkatkan hal-hal yang positif serta mengurangi atau menghambat halhal yang negatif. Di dalam pesantren, kegiatan evaluasi diri (muhasabah atau monitoring) merupakan hal yang sangat ditekankan, baik terkait dengan masalah pemahaman santri terhadap kondisi dan kompetensi dirinya maupun berkenaan dengan tingkat pemahaman dan komitmen mereka terhadap ajaran Islam, mulai dari aspek ibadah harian, seperti shalat wajib, shalat sunnah, puasa, tilawah, hafalan Al-Qur'an, dan sebagainya, sampai kepada persoalan akidah, akhlak, dan seterusnya. Proses ini biasanya terjadi pula ketika kyai dan para ustadz di pesantren melakukan test lisan, bertanya, dan mengamati periaku para santrinya. Hasil supervisi ini biasanya akan disampaikan secara individual kepada seorang santri secara empat mata atau secara umum umum di hadapan para santri saat ada kesempatan pada pertemuan forum besar pesantren.

\section{Proses Pengembangan Kepribadian Santri Melalui Bimbingan Individual}

Proses ini dapat ditangkap dari adanya praktek (tradisi) sowan terhadap kyai yang ada dalam masyarakat pesantren. Di ketiga pesantren yang menjadi lokasi penelitian ini, setiap santri biasanya memiliki keempatan untuk menghadap dan berbicara kepada kyai dalam sebuah kesempatan face to face (empat mata). Kesempatan ini bisa terjadi kerena berangkat dari kemauan seorang santri untuk menghadap (konsultasi) tentang diri dan masalahnya atau karena Sang Kyai sendiri yang memanggil yang bersangkutan untuk menghadap. Dalam kesempatan seperti ini, sang santri biasanya akan menghadap kyai dengan diawali mencium tangan kyai saat jabat tangan, duduk bersimpuh, dan menceritakan segala permasalahan pribadinya (curhat). Selanjutnya, sang kyai akan mendengarkan, bertanya, dan berusaha memahami permasalahan santrinya, kemudian menasihati dan mendo'akan agar santrinya berhasil (sukses) atau dimudahkan urusannya. Termasuk dalam proses ini adalah saat santri pertama kali datang atau mendaftarkan dirinya ke pesantren. Biasanya, si santri bersama orangtuanya akan terlebih dahulu sowan kyai melakukan ijab-kabul (serah-terima), yaitu dari si orangtua santri yang memberi amanah kepada kyai yang akan menerima amanah sebagai pengasuhnya. Dalam kesempatan ini biasanya santri (dan orangtua) akan mendapatkan pencerahan tentang perikehidupan pesantren dan diakhiri do'a dan harapan agar si santri betah dan sukses belajarnya.

\section{Proses Pengembangan Kepribadian Santri melalui Pengakraban Hubungan (Encounter).}

Pengakraban hubungan, yaitu meningkatkan hubungan baik dengan pribadi-pribadi tertentu, misalnya anggota keluarga, teman, kelompok pengajian, dan rekan kerja, sehingga tercipta suasana saling percaya, saling membutuhkan, dan saling membantu. Hal inilah yang menjadi karakteristik pesantren sebagai lembaga pendidikan yang memiliki budaya komunal yang kental. Sebagaimana telah diuraikan sebelumnya, salah satu aspek yang menjadi kekuatan pesantren adalah diterapkannya nilai-nilai $u k h u w a h$ secara konkrit dalam kehidupan sehari-hari. Misalnya, kebersamaan saat makan bersama, tidur bersama, belajar bersama, dan menjalankan tugas dari pesantren dalam kepanitiaan bersama, dan sebagainya. Dengan daya dan kekuatan dari Allah SWT, sistem ini akan mampu menghimpun komunitas pesantren yang tulus, memudahkan hubungan antar mereka, mengarahkan mereka kepada teladan dalam hidup, memperkokoh ikatan persatuan mereka, dan mengangkat persaudaraan mereka dari tataran kata-kata dan teori ke tingkat operasional. Apabila ada anggota kelompok yang tertimpa musibah, maka anggota yang lain akan berlomba-lomba untuk meringankan beban saudaranya. Oleh karena itu, setiap santri diharapkan untuk turut menyukseskan sistem ini di lingkungan mereka masing-masing. Dengan cara ini, Allah senantiasa memberikan perlindungan-Nya kepada mereka. Jika mereka mampu menunaikan kewajiban-kewajiban ini, baik yang bersifat individual, sosial, maupun finansial, maka pilar-pilar pesantren ini pasti akan eksis. Akan tetapi, apabila mereka menyia-nyiakannya, maka sistem ini akan melemah dan akhirnya hancur. Intensitas hubungan (encounter) dalam pesantren dapat dilihat pada nilai saling pengertian (ta'aruf), saling memahami (tafahum), dan tanggung jawab 
sosial (takaful). Tiga landasan ini ditulis dalam kata-kata yang menunjukkan makna kerja sama, yaitu ta'aruf, tafahum, dan takaful. Ta'aruf mengandung makna 'saling memperkuat rasa persaudaraan di antara sesama santri. Saling memahami (tafahum) mengandung maksud adanya pemahaman yang benar tentang Islam dan keinginan untuk diatur dengan ajaran-ajarannya dan secara pribadi bertanggungjawab kepada saudaranya. Takaful (tanggung jawab sosial) didefinisikan sebagai esensi rasa persaudaraan, yaitu ditunjukkan dengan saling peduli dan memberi perhatian.

\section{Proses Pengembangan Kepribadian Santri melalui Ibadah dan Do'a}

Pembiasaan ibadah adalah kegiatan menjalin hubungan dengan Allah denga melakukan ibadah-ibadah mahdhah (khusus) seperti shalat, puasa, dzikir, dan ibadah dalam arti umum, yaitu berbuat kebajikan, dengan niat semata-mata karena Allah. Secara sadar maupun tidak, jika hal ini dilakukan secara konsisten, maka akan memunculkan kualitas-kualitas terpuji pada orang yang melakukannya, sebagaimana firman Allah: "Sesungguhnya shalat itu mencegah (manusia) dari perbuatan keji dan mungkar, dan sesungguhnya mengingat kepada Allah itu merupakan (kekuatan) yang paling besar" (Q.S. Al-Ankabut: 45).

Di dalam pesantren terdapat mekanisme pembiasaan dan saling mengevaluasi secara bersama-sama terhadap amalan-amalan ibadah rutin, baik harian, pekanan, ataupun bulanan, misalnya dalam hal: shalat, puasa, hafalan, tilawah, dzikir, do'a, dan sebagainya.Secara periodik, kyai biasanya mengajak para santrinya untuk mengevaluasi amalan ibadah mereka. Secara periodik pula mereka melakukan ibadah secara bersama-sama (jama'ah) misalnya shalat malam, tadarus, shalawat al banrzanji, berdo'a, tahlilan, yasinan, atau puasa sunnah. Dzikir, do'a, dan shalawat yang ditradisikan untuk dibaca secara bersama atau mekanisme saling mendo'akan di antara warga pesantren adalah aspek penting yang selama ini tidak dibahas dalam kajian pengembangan kepribadian sekuler. Inilah yang menjadi kekuatan tersendiri yang harus dikembangkan dalam khazanah bimbingan dan konseling Islam, baik dalam seting individual maupun kelompok.

\section{Proses Pengembangan Kepribadian Santri melalui Pendalaman Nilai.}

Pendalaman nilai dalam komunitas pesantren merujuk pada upaya untuk memahami dan memenuhi nilai-nilai ajaran Islam yang merupakan sumber makna hidup. Secara garis besar, nilainilai yang perlu dipahami, dihayati, ditanamkan, dan diaktualisasikan dalam konteks kehidupan pesantren mencakup dua dimensi ajaran Islam, yaitu hablun minallah (hubungan manusia dengan Allah) dan hablun minannas (hubungan manusia dengan Allah). Sebagaimana telah diuraikan sebelumnya, nilai-nilai itu antara lain meliputi keilmuan, kemandirian, tanggungjawab, kesederhanaan, kebersamaan (persudaraaan), kepemimpinan, dan spiritual. Nilai-nilai inilah yang menjadi keunikan pesantren dalam membentuk kepribadian para santrinya.

\section{Analisis Model Pengembangan Kepribadian Muslim di Pesantren}

Berdasarkan hasil penggalian nilai-nilai yang menjadi landasan pengembangan kepribadian dan proses pengembangan keribadian santri yang ada di pesantren, penulis selanjutnya mencoba menganalisis dan merumuskan bagaimana sesungguhnya model pengembangan kepribadian muslim yang ada di pesantren ditinjau dari teori pengembangan pribadi. Model pengembangan kepribadian muslim yang ada di pesantren sesungguhnya dapat dikatakan sebagai sebuah model pengembangan kepribadian yang berorientasi pada nilai-nilai religius yang dipahami dan dipraktekkan oleh komunitas pesantren, misalnya meliputi semangat keilmuan, kemandirian, tanggungjawab, kesederhanaan, kebersamaan (persaudaraaan), kepemimpinan, keikhlasan, dan sebagainya.

Jika dilihat dari teori pengembangan kepribadian, praktek pengembangan kepribadian muslim yang ada di pesantren dapat pula dikategorikan sebagai sebuah model pengembangan kepribadian dengan pendekatan konten dan rentang kehidupan. ${ }^{819}$ Artinya, Pengembangan

${ }^{819}$ Abdul Mujib (2005). Kepribiadian Psikologi Islam. Jakarta: Raja Grafindo Persada, hal. 388. 
kepribadian yang ditempuh dengan dua pendekatan, yaitu pendekatan konten (materi) dan pendekatan rentang kehidupan. Pendekatan konten meliputi serangkaian metode dan materi dalam pengembangan kepribadian yang secara hirarkis dilakukan oleh individu, dari jenjang terendah sampai ke yang paling tinggi, tanpa mengenal batasan usia, untuk mencapai kualitas tertinggi. Asumsi dari pendekatan ini adalah bahwa untuk melakukan pengembangan diri ke arah yang lebih baik, setiap individu dapat menggunakan materi dan metode apa saja. Konten yang dimaksud adalah seluruh materi kitab kuning ynag diajarkan dan dikaji di pesantren. Sedangkan pendekatan rentang kehidupan meliputi serangkaian perilaku yang dikaitkan dengan tugas-tugas perkembangan menurut rentang usia. Asumsi pendekatan ini adalah bahwa dalam setiap rentang kehidupan, setiap individu memiliki tugas perkembangan yang harus diperankan menurut jenjang usia. Hal ini sesuai dengan kondisi santri yang memang sedang pada usia perkembangan, di mana mereka umumnya adalah usia remaja dan dewasa awal.

Dilihat dari teori logoanalisis, maka proses pengembangan kepribadian muslim yang ada di pesantren mengandung komponen pemahaman, keteladanan, pembiasaan, ibadah, dan pendalaman nilai. Nilai-nilai dan proses pengambangan kepribadian muslim di pesantren ini sesungguhnya adalah sebuah tradisi hidup (living tradition) yang telah lama dipahami dan dipraktekkan oleh masyarakat pesantren, serta diwariskan dari generasi ke genarasi. Proses ini bertumpu pada relasi dan interaksi yang terjadi antara santri-kyai, santri-ustadz santri-santri. Ikatan-ikatan komunal yang terdapat pada komunitas pesantren menjadi mekanisme pengembangan pribadi santri yang akan membekas pada diri santri yang pada gilirannya akan mengantarkan santri menjadi sosok manusia yang diharapkan akan selalu kompatibel dengan perkembanga jaman.

Dilihat dari berbagai proses atau metode pengembangan kepribadian santri di atas, penulis menangkap adanya sebuah potensi terbesar yang seharusnya bisa menjadi landasan pengembangan kepribadian di pesantren. Hal itu adalah prinsip otoritas yang dimiliki oleh sang Kyai. Otoritas di sini dimaksudkan sebagai pemahaman yang dimiliki oleh Kyai terhadap sumbersumber keislaman, yaitu Al-Qur'an, Hadits, dan kitab-kitab rujukan, terutama bidang akhlak dan tasawuf, yang ditulis para ulama seperti Al-Ghazali, Ibnu Qayyim, dan lainnya. Jika para pemangku pesantren menyadari bahwa berbagai sumber keislaman tersebut menyimpan berbagai petunjuk etis dan praktis bagi pelaksanaan pengembangan kepribadian pesantren, maka hal ini merupakan modal yang luar biasa besar bagi suksesnya aktifitas pengembangan pribadi santri dalam berbagai aspeknya.

Model pengembangan kepribadian muslim yang telah dipraktekkan dalam komuntas pesantren ini menurut hemat penulis dapat dikatakan sebagai sebuah jawaban terhadap kebutuhan akan pendekatan pengembangan kepribadian yang sesuai dengan konteks budaya dan agama yang ada di masyarakat. Hal ini kemudian memunculkan wacana perlunya pengembangan pribadi yang disebut dengan indigenous personality development, yaitu sebuah pola pengembangan kepribadian yang berakar pada nilai-nilai, cara pandang, atau tradisi yang ada dalam sebuah komunitas (kelompok masyarakat). Wacana ini tidak dapat dilepaskan dari berkembangnya wacana indigenous psychology, yaitu upaya membangun psikologi yang mempertimbangkan faktor-faktor seperti sosial, politik, budaya, sejarah, agama, dan ekologi, yang membuat setiap kelompok budaya atau individu sebagai agen bagi tindakan mereka sendiri. Sejumlah psikolog pribumi menganjurkan studi ilmiah terhadap perilaku dan proses psikologis manusia dalam sebuah konteks yang bermakna secara budaya. Sebagai contoh, para psikolog di China telah melakukan pengembangan model pengembangan kepribadian yang dibangun berdasarkan nilai-nilai yang ada dalam tiga budaya besar yang dipandang sangat berpengaruh dalam kehidupan masyarakat China, yaitu Confusianisme, Taoisme, dan Budhisme. Dalam konteks masyarakat muslim, seiring dengan pesatnya perkembangan umat muslim di berbagai negara, utamanya di negara Barat, semakin besar pula kesadaran para ahli Psikologi dan Konseling terhadap pengembangan model bimbingan yang dibangun berdasarkan atas pemahaman yang mendalam terhadap nilai-nilai atau ajaran 
Islam, baik yang tercantum dalam sumber tertulis yaitu Al-Qur'an dan Hadits maupun yang diyakini dan dipraktekkan oleh umat muslim. .820

\section{E. Kesimpulan}

Berdasarkan uraian di atas, dapat disimpulkan bahwa model pengembangan kepribadian muslim yang dipraktekkan oleh komunitas pesantren, dilandasi oleh beberapa prinsip dan nilainilai religius yang dipahami dan dipraktekkan oleh komunitas pesantren, misalnya meliputi semangat keilmuan, kemandirian, tanggungjawab, kesederhanaan, kebersamaan (persaudaraaan), kepemimpinan, keikhlasan, dan sebagainya.

Dilihat dari teori pengembangan kepribadian, praktek pengembangan kepribadian muslim yang ada di pesantren dapat pula dikategorikan sebagai sebuah model pengembangan kepribadian dengan pendekatan konten dan rentang kehidupan. Artinya, Pengembangan kepribadian yang ditempuh dengan dua pendekatan, yaitu pendekatan konten (materi) dan pendekatan rentang kehidupan. Dilihat dari teori logoanalisis, maka proses pengembangan kepribadian muslim yang ada di pesantren mengandung komponen pemahaman, keteladanan, pembiasaan, ibadah, dan pendalaman nilai. Nilai-nilai dan proses pengambangan kepribadian muslim di pesantren ini sesungguhnya adalah sebuah tradisi hidup (living tradition) yang telah lama dipahami dan dipraktekkan oleh masyarakat pesantren, serta diwariskan dari generasi ke genarasi. Proses ini bertumpu pada relasi dan interaksi yang terjadi antara santri-kyai, santri-ustadz santri-santri. Ikatan-ikatan komunal yang terdapat pada komunitas pesantren menjadi mekanisme pengembangan pribadi santri yang akan membekas pada diri santri yang pada gilirannya akan mengantarkan santri menjadi sosok manusia yang diharapkan akan selalu kompatibel dengan perkembanga jaman.

Dilihat dari berbagai proses atau metode pengembangan kepribadian santri di atas, penulis menangkap adanya sebuah potensi terbesar yang seharusnya bisa menjadi landasan pengembangan kepribadian di pesantren. Hal itu adalah prinsip otoritas yang dimiliki oleh sang Kyai. Otoritas di sini dimaksudkan sebagai pemahaman yang dimiliki oleh Kyai terhadap sumbersumber keislaman, yaitu Al-Qur'an, Hadits, dan kitab-kitab rujukan, terutama bidang akhlak dan tasawuf, yang ditulis para ulama seperti Al-Ghazali, Ibnu Qayyim, dan lainnya. Jika para pemangku pesantren menyadari bahwa berbagai sumber keislaman tersebut menyimpan berbagai petunjuk etis dan praktis bagi pelaksanaan pengembangan kepribadian pesantren, maka hal ini merupakan modal yang luar biasa besar bagi suksesnya aktifitas pengembangan pribadi santri dalam berbagai aspeknya.

Model pengembangan kepribadian muslim yang telah dipraktekkan dalam komuntas pesantren ini menurut hemat penulis dapat dikatakan sebagai sebuah jawaban terhadap kebutuhan akan pendekatan pengembangan kepribadian yang sesuai dengan konteks budaya dan agama yang ada di masyarakat. Hal ini kemudian memunculkan wacana perlunya pengembangan pribadi yang disebut dengan indigenous personality development, yaitu sebuah pola pengembangan kepribadian yang berakar pada nilai-nilai, cara pandang, atau tradisi yang ada dalam sebuah komunitas (kelompok masyarakat). Wacana ini tidak dapat dilepaskan dari berkembangnya wacana indigenous psychology, yaitu upaya membangun psikologi yang mempertimbangkan faktor-faktor seperti sosial, politik, budaya, sejarah, agama, dan ekologi, yang membuat setiap kelompok budaya atau individu sebagai agen bagi tindakan mereka sendiri. Dalam konteks masyarakat muslim, seiring dengan pesatnya perkembangan umat muslim di berbagai negara, utamanya di negara Barat, semakin besar pula kesadaran para ahli Psikologi dan Konseling terhadap pengembangan model bimbingan yang dibangun berdasarkan atas pemahaman yang mendalam terhadap nilai-

${ }^{820}$ Lihat Muskinu Fuad, Halaqah: Model Bimbingan Kelompok Dalam Manhaj Tarbiyah, dalam Jurnal Ilmu Dakwah IAIN Semarang, 2013 dan lihat pula Abdullah (2009). Toward a Concept of Islamic Personality. [Online]. Tersedia:

http://www.crescentlife.com/articles/islamic\%20psych/conceptofislamicpersonality.htm

[2 Januari 2009]. 
nilai atau ajaran Islam, baik yang tercantum dalam sumber tertulis yaitu Al-Qur'an dan Hadits maupun yang diyakini dan dipraktekkan oleh sebuah komunitas, misalnya pesantren.

Untuk sampai pada temuan yang lebih valid, konseptual, dan operasional, hasil penelitian ini sesungguhnya masih memerlukan berbagai penelitian lanjutan yang bersifat eksperimental dan developmental untuk menguji efektivitas model pengembangan kepribadian muslim ala pesantren, jika model ini akan diterapkan dalam konteks yang lebih luas dan beragam, di luar pesantren. Kepada para pemangku pesantren pada umumnya, penulis menyarankan agar sistem pesantren ini dapat dikembangkan lagi secara lebih inklusif agar dapat diterapkan di masyarakat luas. Jadikanlah sistem pesantren ini menjadi miliki semua umat Islam, baik di Indonesia pada khususnya dan dunia Islam pada umumnya. Bagi para peminat kajian pengembangan kepribadian, hasil penelitian ini dapat dijadikan sebagai salah satu pijakan bagi pengembangan model pengembangan kepribadian Islami, karena digali dari pandangan hidup, tradisi, dan praktek sebagian masyarakat muslim, yaitu pesantren. Model yang telah dirumuskan dalam penelitian masih bersifat garis besar dan konseptual. Untuk itu, jika akan diterapkan dalam pola pengembangan kepribadian secara lebih praktis, sebagaimana layaknya sebuah teori pengembangan kepribadian, maka model ini harus diturunkan ke dalam bentuk yang lebih teknis dan operasional.

\section{Daftar Pustaka}

Abdul Mujib (2005). Kepribadian dalam Psikologi Islam. Jakarta: Raja Grafindo Persada

Abdullah, Abdul Lateef (2009). Toward a Concept of Islamic Personality. [Online]. Tersedia: http://www.crescentlife.com/articles/islamic\%20psych/conceptofislamicpersonality.htm [2 Januari 2009].

Alwasilah, A. Chaedar (2009). Pokoknya Kualitatif v: Dasar-dasar Merancang dan Melakukan Penelitian Kualitatif. Jakarta: Pustaka Jaya.

Arvey, R. D. "Genetics, Twin, and Organizational Behavior, " Research in Organizational behavior, vol. 16, Greenwich CT: JAI Press, 1994, hal 65-66.

Bashori, Khoiruddin (2003). Problem Psikologis Kaum Santri: Resiko Insekuritas Kelekatan. Yogyakarta: FKBA

Bastaman, H.D. (1995). Integrasi Psikologi dengan Islam, Menuju Psikologi Islami. Yogyakarta: Pustaka Pelajar

Bastaman, H.D. (2007). Logoterapi: Psikologi untuk Menemukan Makna Hidup dan Meraih Hidup Bermakna. Jakarta: Rajawali Pers.

Creswell, John W. (1998). Qualitative Inquiry and Research Design: Choosing Among Five Traditions, California: Sage Publication, Inc.

Dhofier, Zamakhsyari (1994). Tradisi Pesantren: Studi Tentang Pandangan Hidup Kyai. Jakarta: LP3ES. Cet. Keenam

Fuad, Muskinul (2015). Pengembangan Kepribadian Muslim melalui Halaqah: Model bimbingan Kelompok dalam manhaj Tarbiyah, Purwokerto: STAIN Press

Fuad, Muskinul (2013). Halaqah : Model Bimbingan Kelompok Dalam Manhaj Tarbiyah, dalam Jurnal Ilmu Dakwah Fakultas Dakwah IAIN Semarang

Fuad, Muskinul dan Budiono, Alif (2012) "Pola Kelekatan di Kalangan Santri Usia Remaja Awal: Studi Kasus di Pondok Pesantren Anwarussholihin Pamujan Teluk, Banyumas" dalam Jurnal Personifikasi Vol 3, Nomor 2, November 2012 
Hasyim, Yusuf (2008). Model Penelitian Kultur Pendidikan Islam Dr. Mastuhu Tentang Dinamika Sistem Pendidikan Pesantren. [Online]. Tersedia:

https://gurubangsaku.wordpress.com/2008/10/28/dinamika-sistem-pendidikanpesantren

https://id.wikipedia.org/wiki/Kepribadian

https://id.wikipedia.org/wiki/Pesantren

http://pp-darussalam.blogspot.com/p/profil.html

http://www.thohiriyyah.com/2011/09/388.html

http://p2m.stainpurwokerto.ac.id/ponpes/detail/8,

http://satelitnews.co/berita-sekilas-an-najah.html\#ixzz3kYPOblIF

http://roqibstain.blogspot.com/,

http://mohroqib.blogspot.com/

Lukens-Bull, Ronald A. (1998). Teaching Morality: Javanese Islamic Education in Globalizing Era. Disertasi di Arizona University Southeast Asia

Madjid, Nurcholis (1997), Bilik-Bilik Pesantren Sebuah Potret Perjalanan, Jakarta: Paramadina

Mastuhu, Dinamika Sistem Pendidikan Pesantren, Jakarta: INIS, 1994.

Matta, Anis (2010). Delapan Mata Air Kecemerlangan. Jakarta: Tarbawi Press

McCrae, R. R. Reinterpreting the Myers-Briggs Type Indicator from the Perspective of the Five Factor Models of Personality, Journal of Personality, Ney York: Wiley, Maret 1989

Najati, M. Utsman (2008). The Ultimate Psychology: Psikologi Sempurna Ala Nabi SAW. Bandung: Pustaka Hidayah.

Parker, Ian (2005). Psikologi Kualitatif. Yogyakarta: Penerbit ANDI.

Prasodjo, Sudjono (1982). Profil Pesantren, Jakarta: LP3ES

Rakhmat, Jalaluddin (2003). Islam Aktual. Bandung: Mizan

Rakhmat, Jalaluddin (2001), Metode Penelitian Komunikasi, Bandung: Rosda

Robbins, Stephen P.; Judge, Timothy A. (2008). Perilaku Organisasi Buku 1, Jakarta: Salemba Empat.

Spradley, J. P. (1997). Metode Etnografi. Yogyakarta: PT Tiara Wacana.

Sugiono (2008). Metode Penelitian Pendidikan Pendekatan Kuantitatif Kualitatif dan $R \& D$. Bandung: Alfabeta.

Suparjo (2014). Komunikasi Interpersonal Kyai-Santri: Keberlangsungan Tradisi Pesantren di Era Modern. Purwokerto: STAIN Press

www.pesmaannajah.org

Yusuf, Syamsu dan Nurihsan, A. Juntika (2008). Teori Kepribadian. Bandung: Rosda. 